\title{
Correction
}

\section{Correction to: Efficacy evaluation of neurofeedback applied for treatment of central neuropathic pain using machine learning}

\author{
Mohammed Gamil Mohammed Saif ${ }^{1,2,3}$ - Muhammad Abul Hasan ${ }^{1,2} \cdot$ Aleksandra Vuckovic $^{4} \cdot$ Matthew Fraser $^{5}$. \\ Saad Ahmed Qazi ${ }^{6,2}$
}

Published online: 21 July 2021

(c) The Author(s) 2021

\section{Correction to: SN Applied Sciences (2021) 3:58 https://doi.org/10.1007/s42452-020-04035-9}

The list of authors was incorrect in the initial online publication, and the Acknowledgments section was missing. The original article has been corrected.

Open Access This article is licensed under a Creative Commons Attribution 4.0 International License, which permits use, sharing, adaptation, distribution and reproduction in any medium or format, as long as you give appropriate credit to the original author(s) and the source, provide a link to the Creative Commons licence, and indicate if changes were made. The images or other third party material in this article are included in the article's Creative Commons licence, unless indicated otherwise in a credit line to the material. If material is not included in the article's Creative Commons licence and your intended use is not permitted by statutory regulation or exceeds the permitted use, you will need to obtain permission directly from the copyright holder. To view a copy of this licence, visit http://creativecommons. org/licenses/by/4.0/.

Publisher's Note Springer Nature remains neutral with regard to jurisdictional claims in published maps and institutional affiliations.

The original article can be found online at https://doi.org/10.1007/s42452-020-04035-9.

Mohammed Gamil Mohammed Saif, saifmohammed955@gmail.com | Department of Biomedical Engineering, NED University of Engineering and Technology, Karachi, Pakistan. ${ }^{2}$ Neurocomputation Laboratory, National Center of Artificial Intelligence, Karachi, Pakistan. ${ }^{3}$ School of Engineering, Vladimir State University, Vladimir, Russia. ${ }^{4}$ Centre for Rehabilitation Engineering, Biomedical Engineering Division, School of Engineering, University of Glasgow, Glasgow, UK. ${ }^{5}$ Queen Elizabeth National Spinal Injuries Unit, Southern General Hospital, Glasgow, UK. ${ }^{6}$ Department of Electrical Engineering, NED University of Engineering and Technology, Karachi, Pakistan. 